\title{
POCKels CELl PULSE-STACKERS
}

\author{
R. C. Harney
}

January 7, 1976

\section{MASTEE}

Prepared for L'.S. Energy Research \& Development Administration under contract No. W-7405-Eng-48

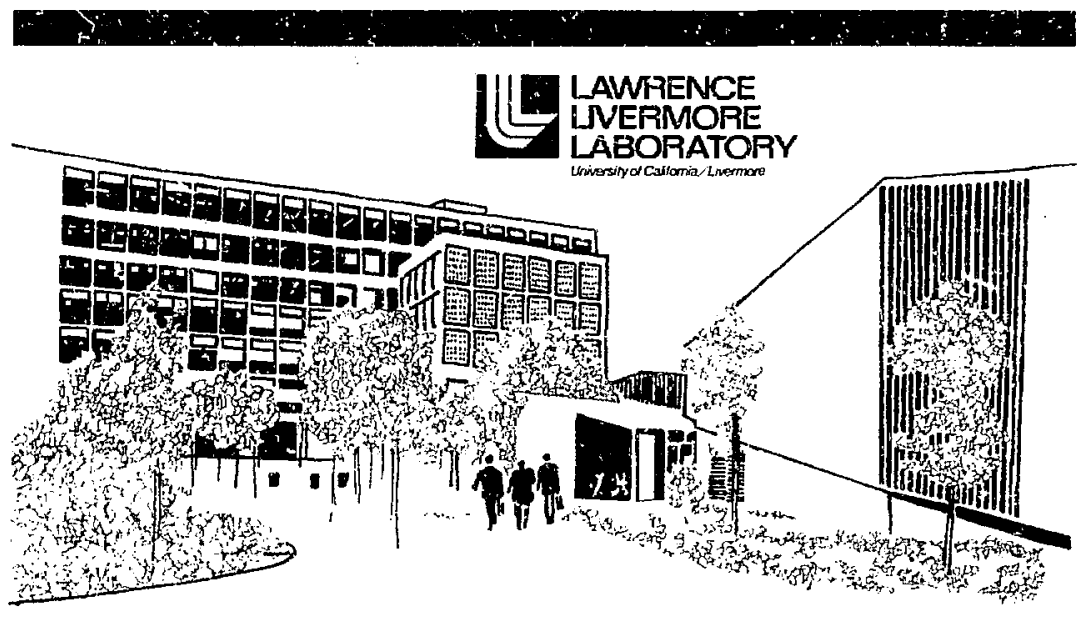


NOTHCE

"This report was prepared as an acrount of work spousored by the Uniled Statss Guvernment. Neith ar the United States nor the United Stares Energy Rescarch \& Development Admin istration, nor any of their smployecs, nor any of theit contractors. subcontractors, or theit employees, makes any warranty, express or implied, or assumes any legal liability or responsibiliey for the eccuracy. completeness as usefuness of an! information, apparatus, product or process disclosed, or epresents that its use wowld not infringe in :ivately-awned rights."

Printed in the United States of America Available from

National Technical Information Service

U.S. Department of Commerce 5285 Port Royal Road

Springfield, Virginia 22151

Price: Printed Copy $\$$ *; Microfiche $\$ 2.25$

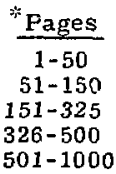

NTIS

Selling Price

$\$ 4.00$

$\$ 5.45$

$\$ 7.60$

$\$ 10.60$

$\$ 13.60$ 


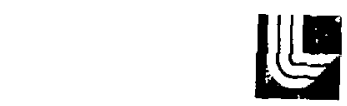

\section{LAWRENCE LVERMOFE LABORATOFY}

Univarsity of Caffomia Lvamore, Caffornia 94550

\section{UCRL-51908 \\ POCKELS CELL PULSE-STACKERS}

R. C. Harnty

MS. daze: January 7, 1976

\begin{tabular}{|c|}
\hline 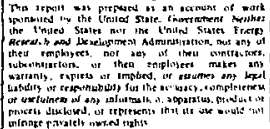 \\
\hline
\end{tabular}




\section{POCKELS CELL PULSE-STACKERS}

\section{Abstract}

The general transmission characteristics of a pulse-stacking system consistitig of an etalon and a cylindrical-ring electrode Pockels ce11 Q-switch are discussed. A voltage pulse-forming network capatle of switching the Pockels cell transmission on the necessary time scales is presented and the vutputs of a simple pulse-stacker configuration are calculated for different voltage waveforms. These results indicate that an efficient ( $\sim 1 \%$ total pulse energy transmission) Pockels cell pulse-stacker can be constructed, which can provide a variable, fasterthan-exponential rise in transmitted pulse intensity.
The current schemes for achieving net energy gain from laser-fusion microexplosions require adiabatic compression of the fuel by tallored laser pulses whose intensities rise in a peculiar faster-than-exponential fashion. ${ }^{1-3}$ As pulses with the desired behavior cannot be generated directly by a laser oscillator, some means of modifying the original Intensity distribution mist be found. One method, known as pulse-stacking, is to splitt a single pulsa Into a number of pulses, change their intensities by approprlate amounts, and recombine them with appropriate delays to yfeld a pulse of the desired intenaity distribution. Numerous pulse-stacking schemes have been proposed In the past. 4 Among these, passive schenes have been noteworthy because they require a1most no attention after they have been fabricated and aligned. However, these schemes are generally handicapped because a single device can only provide a narrow range of pulse durations and risetimes. In this work, we found that a simple active pulse-stacker, consisting of an etalon and a cylindrical-ring electrode (CRE) Pocke1s ce11, could generate extremely flextble risetimes and pulse durations. We belfeve that this type of device can be invaluable during the research phase of laserfusion programs.

Figure 1 illustrates the basic design of this type of pulse-stacker. A single subnanosecond pulse incident 
on the etalon generates a train of pulses whose amplitudes decrease in time, As this pulse train enters a CRE Pockels cell placed between crossed polarizers, the voltage across the Pockels cell electrodes is optically switched from the fullwave voltage to zero. This causes the transmission of the pulse train through the second polarizer to rise rapidly from zero to a maximum value and then fall rapidly back to zero. The superposition of the decaylng etalon output on the Pockels cell transilssion yields a putse envelope that rises rapidly in time to a smooth maximum (which occurs somewhat earlier in time than the Pockels cell transmission maximum) and then decays even more rapidly back to zero.

For a pulse of intensity $I_{0}$ inci- dent or. an etalon of spacing $d$, the intensity of the ${ }^{\text {th }}$ output pulse from the etalon is

$$
I_{\text {II }}=I_{0}(1-r)^{2}(1-R)^{2} K^{2 m-2},
$$

where $\pi$ is the reflectivity of the mirror surfaces and $r$ is the reflectivity of the etalon's ather surfaces (Fig. 2). The delay of the $\mathrm{m}^{\text {th }}$ output pulse with respect to the first output pulse is

$$
D_{m}=(m-1) \tau \text {, }
$$

where $\tau=2 d / c$ is the round trip time of the etalon. Musual alignment of the pulses from the etalon is easily accomplished by making the mirror surfaces suffictently parallel. In Fabry-Perot Interferometers, angular

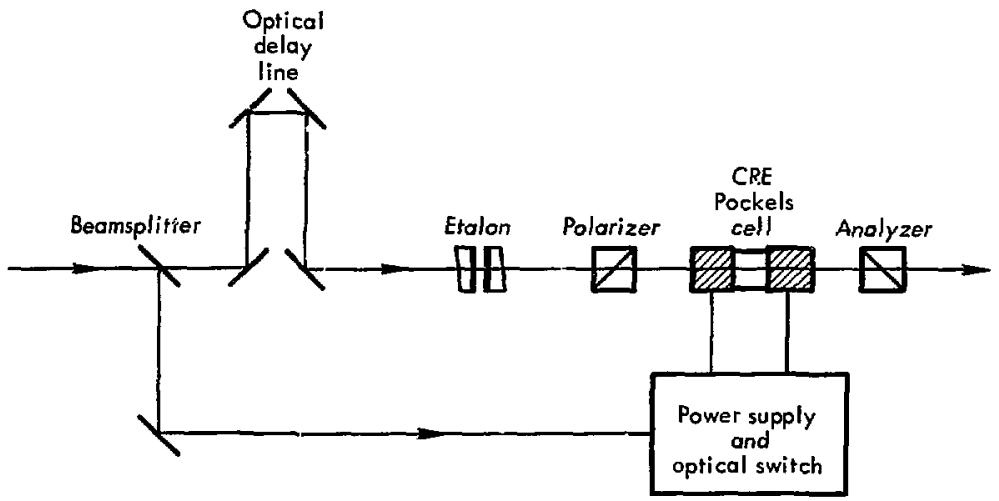

Fłg. 1. Schematic diagram of a Pockels cell pulse-stacker. 


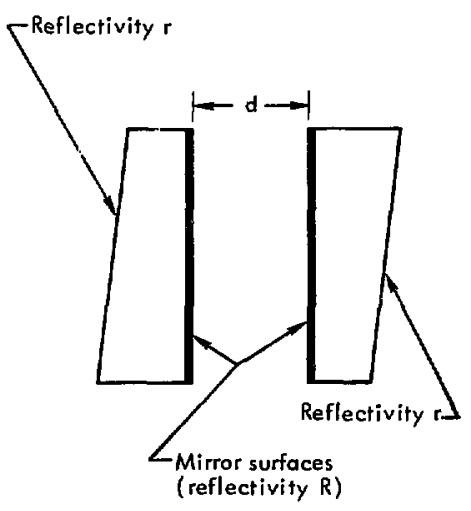

Fig. 2. Detall of the etalon.

alignments of better than 0.1 urad are routinely achieved. This corresponds to a linear displacement of less than $10 \mu \mathrm{m}$ at a distance of $100 \mathrm{~m}$, which is adequate for the applications envisioned. Variation of the pulse spacing is easily achieved by translating one of the mirrors along the bram axis. The etalon mirrors are wedged to prevent unwanted secondary pulseg from appearing in the output pulse train.

When a pulse, initially polarized along the $y$ axis and with a wavevector lying along the 2 axis, propagates through a Pockels cell operated in the longitudinal mode, a component polarized along the $x$ axis is generated. The magnitude of this component is given by

$$
E_{x}=E_{y 0} \sin (\phi / 2)
$$

where $E_{y 0}$ is the magnitude of the incident field and the phase shift $\phi(t)=n_{0}^{3} r_{63} w / c v(t) .5$ The value $n_{0}$ is the linear refractive index of the nonlinear crystal, $r_{63}$ is the appropriate electrooptic coefficient, $\omega$ is the frequency of the incident radiation, and $V$ is the applied voltage. The intensity transmitced by the polarizer-Pockels cell systen is

$$
I_{x}(t)=A I_{y} \sin ^{2}[\phi(t) / 2],
$$

where $A$ is the atcenuation of the polarizers and Pockels cell at maximum transmisston. Combining the etalon output with the Pockels cell transmission yields

$$
\begin{aligned}
I_{m} & \approx I_{0} A(1-R)^{2} R^{2 m-2} \\
& \times(1-r)^{2} \sin ^{2}\left[\frac{\pi}{2} \frac{V(t)}{V_{1 / 2}}\right],
\end{aligned}
$$

where $V_{1 / 2}=\pi c / n_{0}^{3} r_{63} w$ is the halfwave voltage.

To be useful for fusion experimenes, the voltage across the Pockels cell must be switched on nanoseconi time scales w. a picosecond jitter. One method of accomplishing this is with an optically-triggered avalanche transistor circuit similar to those developed for ultrafast streaking cameras. ${ }^{6}$ Such a circuit is shown 
$\therefore$.n Fig. 3. An avilanche transistor string is comected asross the electrodes of the Pockels cell and the ful1-wave voltage is applied. A portion of the Inttial laser pulse strlkes an avalanche phototransistor in the string causing an avalanche breakdown. The voltage across the electrodes collapses to zero in a time of the order of a few nanoseconds with the jitter in beginning the collanse being of the order of 25 ps. This low jitter allows the voltage collapse to be timed to coin- cide with the arrival of the pulse train fron the etalon. A simple optical delay line may bo used ta achieve the timing. A variable capacttor connected across the electrodes allows the duration of the collapse to be varied over more than an order of magnitude.

The voltage waveform during the collapse is approximately one-half cycle of a sinusold. Thus

$$
\begin{aligned}
I_{m}= & I_{0} A(1-R)^{2} R^{2 m-2} \\
& \times(1-r)^{2} \sin ^{2}\left[\frac{\pi}{2} \cos \left(\alpha_{m}\right)+\frac{\pi}{2}\right],
\end{aligned}
$$

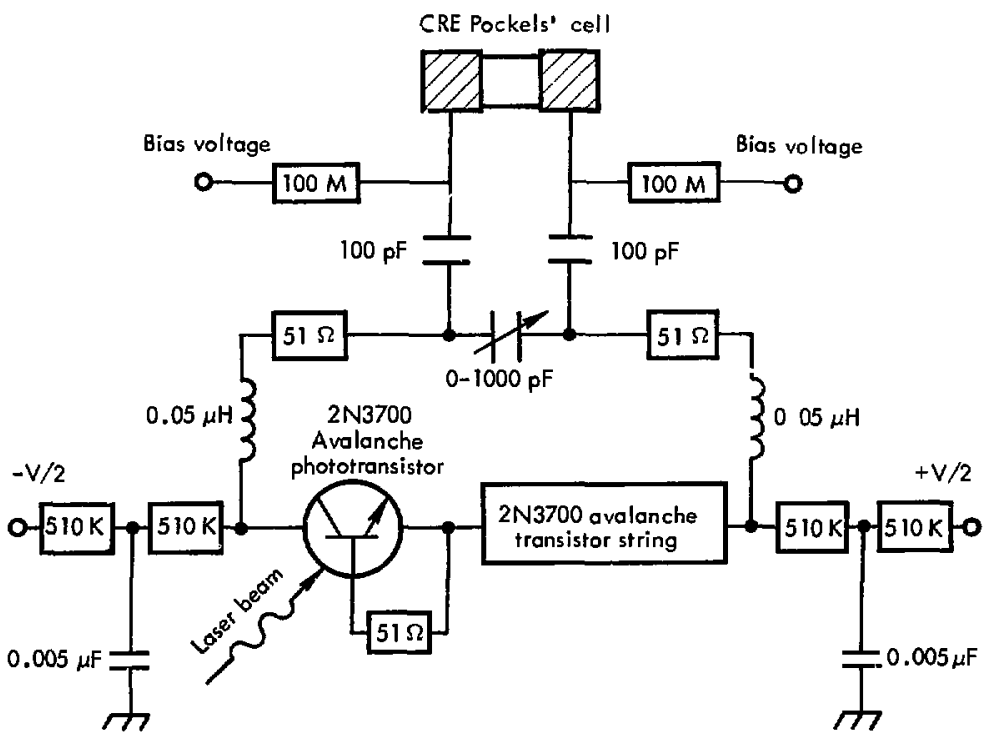

F1g. 3. Circuit diagram of the Pockels cell power supply and optical switch. 


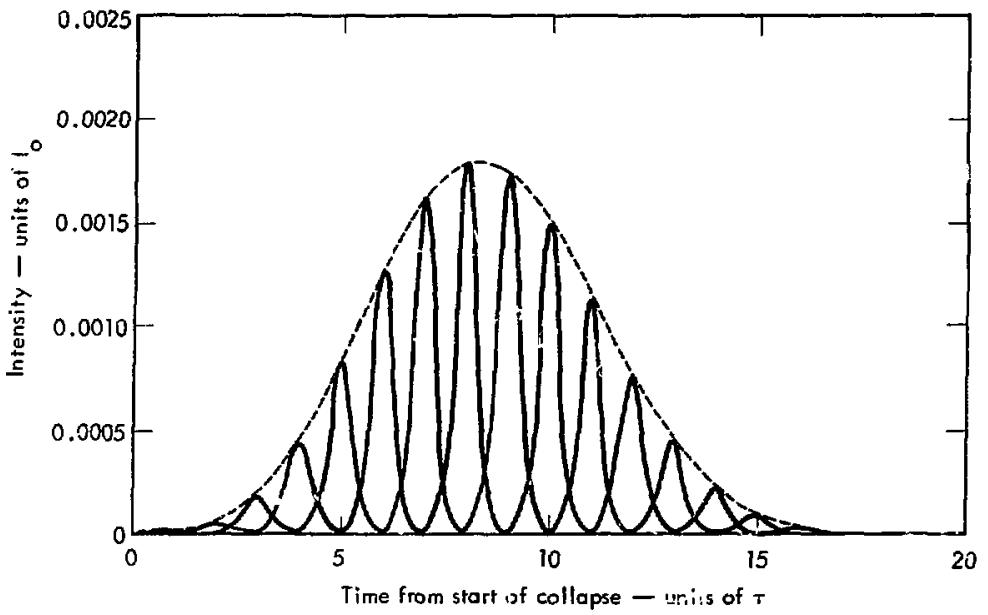

Fig. 4. Output pulise train for $A=i, R=0.9, r=u$, and $v(0)=2 v_{1 / 2}$.

where $\alpha_{\mathrm{m}}=\pi \mathrm{m} \tau / \mathrm{T}$ and $\mathrm{T}$ is the total collapse time. This 15 ploted in F1g. 4 for the case $A=1, t=0$, $R=0.9$, and $T=20 \tau$. Only the rising portion of such a pulse envelope is useful for laser compression applications. However, the existence of the falling portion is not detrimental to these applications because almost all the energy generation will take place shortly after maximum intengity (and compression) are reached. ${ }^{1}$ Summing the intensities transmitted in only the rising portion of the pulse envelope, we find that approximately $0.5 \%$ of the incident pulse intensity is transmitted in a usable form. Higher efficlencles can undoubtedly be obtained by optimizing mirror reflectivities, the number of transmitted pulses, etc.

A siightly different pulse enveloye can be obtained by delaying the arrival of the pulse train at the Pockels cell until after the voltage collapse has begun. The effect of a 10\% delay is shown in Fig. 5 for the same system pacameters as Fig. 4. The efficlency of this arrangement is approximately $0.7 \%$ for these values of the system parameters. Another va:tation is to slightly reduce the Inttial voltage on the Pockel.s cell such that the transmission at $t=0$ is nonzero. Figure 6 
shows the resulting pulse envelope for an Intetal voltage, $v(0)$

$=1.8 \mathrm{v}_{1 / 2}$, and for the same systen parameters as Fig. 4. The efficlency of this arrangement is approximately $0.9 \%$ for these values of the system parameters .

A still different pulse envelope can je obtained by applying a bias voltage across the Pockels cell. For examp:e, Fig. 7 shows the resulting pulse envelope when a bias voltage $V(0)=2 v_{1 / 2}$ and $V(T)=-V_{1 / 2}$ is applied to a system with the parameters of Fig. 4. The effictency of this arrangement is approximately $0.6 \%$ for these values of the system parameters.

It is obvious that by combining any of che possible variations (etalon spacing, initial pulse delay, voltage collapse duration, voltage magnitude, and blas voltage) still differint pulse envelopes can be obtalned. Simllarly, if a different voltage waveform can be generated by some means, pulse envelopes of another general shape can te obtained. In addition, the rise- and fall-timt characteristics of any of these envelopes could be constderably eniranced

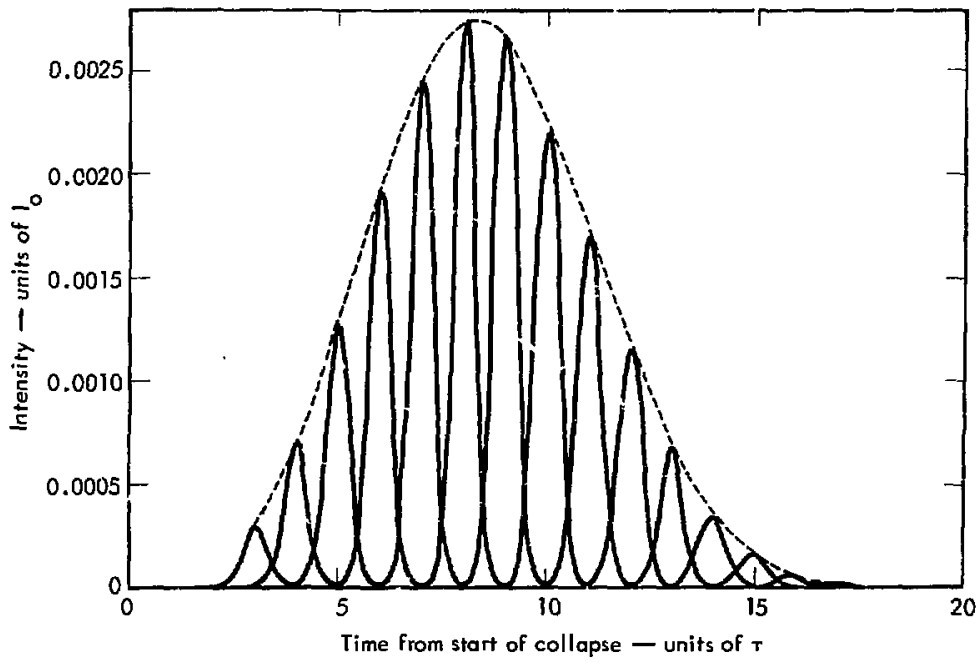

F1g. 5. Output pulse train for $A=1, R=0.9, x=0$, and $V(0)=2 v_{1 / 2}$, with an additional $10 \%$ delay in the arrival of the first pulse at the Pockels cell. 


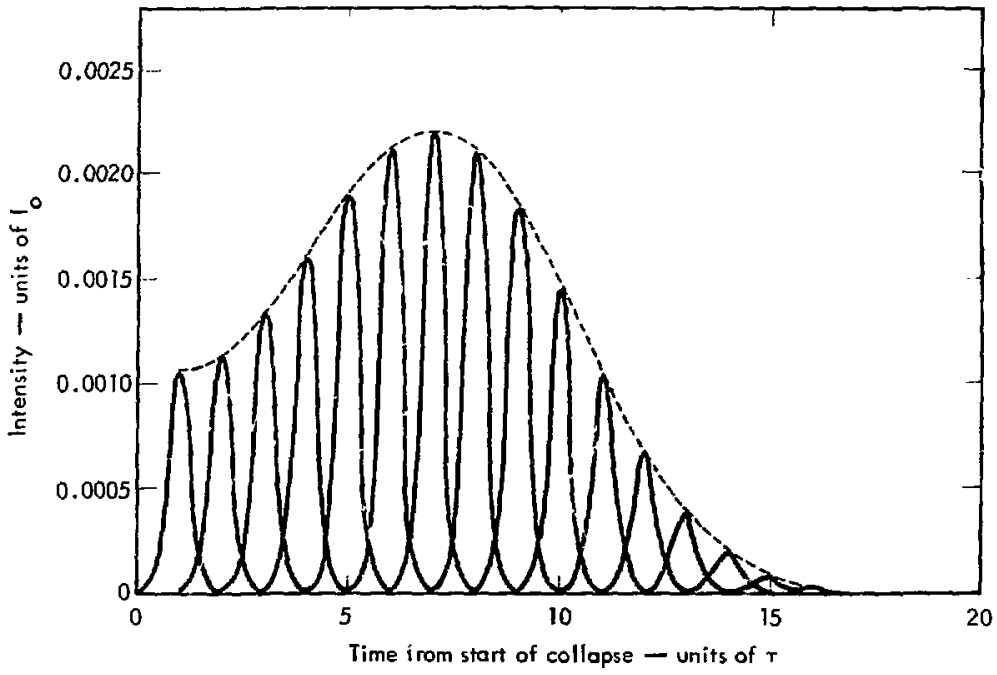

Fig. 6. Outrut pulse train for $A=1, R=0.9, r=0$, and $v(0)=1.8 v_{1 / 2^{*}}$

by placing a saturable absorber after the Pockels cell, although this wonld dramatically reduce the efficiency. On the basis of the foregoing discussion and examples, we conclude that Pockels cell pulse-stackers can provide extremely variable output pulses for a variety of applications. These devices should be invaluable for laser-fuston research. 


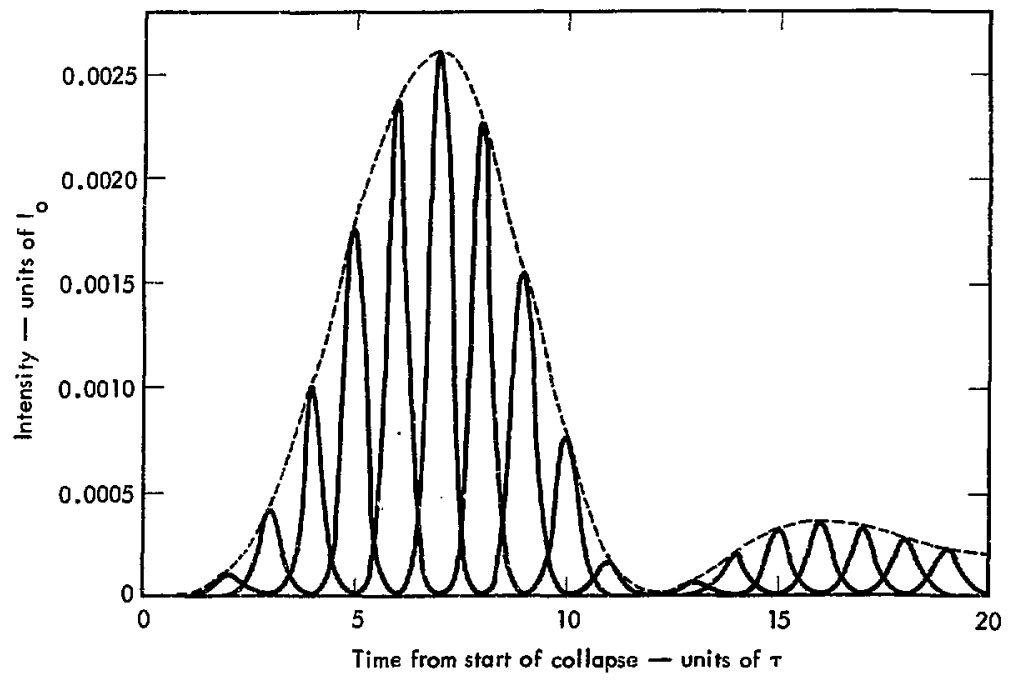

Fig. 7. Output pulse train for $A=1, R=0.9, r=0$, and $v(0)=2 v_{1 / 2}$, with an added bias voltage such that $\mathrm{V}(\mathrm{T})=-\mathrm{V}_{1 / 2}$. 


\section{Acknowledgment}

The author wishes to thank the

Fannie and John Hertz Foundation for

partial support of this work.

\section{References}

I. J. L. Emmert, J. Nuckol1s, and I. Wood, Sc1. Am. 230, 24 (1974).

2. R. E. Kidder, Nuc1. Fusion 14, 797 (1974).

3. G. B. Zimmerman and J. H. Nuckolls, Theory of High Density Laser Fusion, Lawrence Livermore Laboratory, Rept, UCRL-76888 (1975).

4. William D. Founta1n, Lawrence IIvermore Laboratory, private communication (Dec. 1974).

5. A. YarIv, Quanturu Electronics (John Wiley and Sons, New York, 1967), Pp. 293-328.

6. S. W. Thomas and L. W. Coleman, Aup. Phys. Letts. 20, 83 (1972). 